\title{
ELZA SOARES EM FACE DA OUTREMIZAÇÃO: A BUSCA DE UM PROJETO MUSICAL DE SUPERAÇÃO DA CONDIÇÃO DE SUBALTERNIDADE
}

\author{
ELZA SOARES IN FACE OF OTHERING: THE SEARCH \\ FOR A MUSICAL PROJECT TO OVERCOME THE \\ SUBALTERNITY CONDITION
}

\author{
Rafael Lucas Santos da Silva' \\ [https://orcid.org/0000-0002-8596-1008] \\ DOI: 10.30612/raido.v15i37.14488
}

\begin{abstract}
RESUMO: Trata-se aqui de demonstrar resultados preliminares de uma pesquisa que procura examinar a trajetória artística de Elza Soares a partir da teoria pós-colonial, considerando os seus 70 anos de carreira a partir do lócus específico de enunciaçâo subalterna, evidenciando sua condiçăo de mulher negra duplamente oprimida na sociedade brasileira erigida e consolidada sob os valores da cultura patriarcal e colonial. A hipótese de pesquisa é de que, ao longo da sua trajetória artística, existe uma busca de superaçăo da subalternidade, de modo que compreendemos que nos últimos dezoito anos (2002-2020) acentuou-se a interpretaçăo de cançôes de cunho de resistência ao contexto de opressáo e racismo da sociedade brasileira. Isso nos levou a propor que ocorreu "uma reversâo do colonizado-objeto em sujeito dono da sua história e da sua capacidade de reescrever sua história" (BONNICI, 2012, p. 27).
\end{abstract}

Palavras-chave:música popular; ElzaSoares; pós-colonialismo; relaçôesraciais; outremizaçâo.

ABSTRACT: The aim here is to demonstrating preliminary results of a research that seeks to examine the artistic trajectory of Elza Soares from the post-colonial theory, considering his 70 years of career from the specific locus of subordinate enunciation, evidencing his condition a doubly subordinate black woman in Brazilian society built and consolidated on the values of patriarchal and colonial culture. The research hypothesis is that, throughout its artistic trajectory, there is a quest to overcome subalternity, so that we understand that in the last eighteen years (2002-2020) the interpretation of songs of resistance to the context has been accentuated oppression and racism of Brazilian society. This led us to propose that there was "a reversion of the colonized-object in a subject that owns his history and his ability to rewrite his history" (BONNICI, 2012, p. 27).

Keywords: popular music; Elza Soares; post-colonialism; race relations; othering.

1 Universidade Estadual de Maringá (UEM), Maringá, doutorando na área de Estudos Literários, na Linha de Pesquisa Literatura e Historicidade, pelo Programa de Pós-Graduaçâo em Letras. Contato: i3rafael@ hotmail.com 


\section{CONSIDERAÇÕES INICIAIS}

Os olhos de nossos antepassados, negras estrelas tingidas de sangue, elevam-se das profundezas do tempo cuidando de nossa dolorida memória.

A terra está coberta de valas e a qualquer descuido da vida a morte é certa.

A bala nâo erra o alvo, no escuro um corpo negro bambeia e dança. A certidāo de óbito, os antigos sabem, veio lavrada desde os negreiros.

\section{Conceiçăo Evaristo, 2008}

Com mais de 800 cançōes gravadas, năo é tarefa fácil interpretar toda a obra de Elza Soares, cuja atividade artística, que se estende desde a década de 1960, se apresenta, além de extensa, diversificada. Como a pesquisa está em caráter introdutório, no presente artigo apresentamos um recorte analítico com cinco cançôes: "Mulata assanhada", "As polegadas da mulata" e "Mulata verdadeira", retiradas de seus três primeiros álbuns Se acaso você chegasse (1960), A Bossa Negra (1961) e Sambossa (1963); e "A carne", do álbum Do cóccix ao pescoço (2002), e seu mais recente single, "Negâo Negra" (2018)

Atualmente, é difícil pensar em Elza Soares sem ligá-la imediatamente a resistência ao racismo estrutural e ao patriarcado, tendo em vista seus últimos álbuns musicais como Deus é mulher (2018) e Planeta fome (2019). Contudo, a crítica năo tem evidenciado que esse agenciamento de autonomia da cantora é algo recente, de modo que no início da sua carreira ela esteve submetida à opressâo, ao silenciamento e à outremizaçăo ocorridas devido a características ideológicas sobreviventes da colonizaçâo. Sua trajetória artística expôe que a formaçăo histórico-social do Brasil, diferentemente da imagem construída de uma grande democracia racial, possui características autoritárias e excludentes desde sua gênese e que repercutem na contemporaneidade.

Dessa forma, ao cruzarmos as peculiaridades artísticas da obra e da biografia de Elza Soares, deparamo-nos com características marcantes da sociedade brasileira que levantam indagaçóes à teoria pós-colonial, no que se refere aos problemas da nacionalidade/identidade cultural e cidadania, da etnicidade e do racismo, de gênero, subalternidade e outremizaçấo, do binômio exclusâo-inclusāo e da resistência.

A oportunidade de nos debruçarmos sobre essas questōes para compreendê-las por meio das estratégias críticas do pós-colonialismo, acreditamos que nos possibilita contribuir para a representatividade desta teoria para o contexto brasileiro (particularmente na sua relaçăo com a análise de cançōes), uma vez que segundo Thomas Bonnici (2012) é recente a inclusăo da teoria pós-colonial de caráter britânico nos círculos teóricos brasileiros e há uma "notória ausência da América do Sul [...] em toda a crítica pós-colonial em inglês" (BONNICI, 2012, p. 320); e sobremaneira nos possibilita 
contribuir para preencher uma lacuna insatisfatória de empreendimentos analíticos acerca das cançôes compostas e interpretadas por Elza Soares.

Dito isto, o próximo passo será expor brevemente a crítica pós-colonial, com ênfase nas questôes de outremizaçăo e construçăo da identidade, tratadas por Thomas Bonnici (2012), Homi Bhabha (1991), Bill Aschcroft (1998) entre outros, para em seguida abordar as supracitadas cinco cançôes interpretadas por Elza Soares. Ao término do artigo, esperamos demonstrar que é possível apreender uma guinada estético-discursiva na trajetória de Elza Soares, em razăo de "uma reversâo do colonizado-objeto em sujeito dono da sua história e da sua capacidade de reescrever sua história" (BONNICI, 2012, p. 27).

\section{OUTREMIZAÇÃO E IDENTIDADE: ESTRATÉGIAS CRÍTICAS DO PÓS-COLONIALISMO}

Ao tratarmos da teoria pós-colonial, primeiramente năo podemos confundir que o prefixo "pós" designa que a estrutura histórico-social contemporânea é desprovida de colonialismo. Na obra Orientalismo, publicada em 1978 e considerada por muitos teóricos o marco inicial da teoria pós-colonial, Edward Said (1990) argumentou que o desmantelamento das estruturas coloniais năo se resume apenas à desocupaçáo territorial, mas também contempla ideias, imagens e representaçóes que continuam exercendo influência na ex-colônia. Em outras palavras, compreende-se que "o fim do colonialismo enquanto relaçáo política náo acarretou o fim do colonialismo enquanto relaçấo social, enquanto mentalidade e forma de sociabilidade autoritária e discriminatória" (SANTOS, 2004, p. 18).

Em vista disso, a crítica pós-colonial abrange a cultura e as produçôes artísticas, ocupando-se de analisá-las durante e após a dominaçấo imperial europeia, de modo a desnudar seus efeitos sobre as literaturas contemporâneas (BONNICI, 2003). Para cumprir esse objetivo, a teoria pós-colonial abrange uma complexa gama de temas e abordagens, surgidos a partir de uma episteme que visa desconstruir os "discursos ideológicos da modernidade que tentam dar uma normalidade hegemônica ao desenvolvimento das histórias diferenciais de naçōes, raças, comunidades, povos" (BHABHA, 1998, p. 239).

O poder colonial com os seus discursos dominantes produz o sujeito colonial, cuja "subjetividade será produzida pelo discurso que é dominante" (ASCHCROFT et al, 1998, p. 224). Desse modo, essa subjetividade é desprovida de qualquer alteridade, porque no momento em que o discurso colonial se "concentra em construir o colonizado como populaçáo do tipo degenerado, tendo como base uma origem racial para justificar a conquista e estabelecer sistemas administrativos e culturais" (BHABHA, 1991, p. 184), ocorre enfim uma dicotomia sujeito-objeto nas sociedades pós-coloniais, com a qual o sujeito e o objeto pertencem inexoravelmente a uma hierarquia em que o oprimido é fixado pela superioridade moral do dominador (BONNICI, 2012).

Nesse sentido, o termo outremizaçâo [othering] permite conhecer os meandros das posiçóes hierárquicas constituídas pelas práticas discursivas do poder imperial. Bill Aschcroft (1998) esclarece que esse termo foi criado pela teórica Gayatri Spivaki para compreender o processo pelo qual o discurso imperial cria seus "outros", os quais sáo 
dominados por esse mesmo discurso: "a outremizaçăo descreve os vários modos pelos quais o discurso colonial produz seus sujeitos" (ASCHCROFT, 1998, 171).

Essa diferenciaçăo entre Outro/outro implica, pois, que o colonizador relega o colonizado à condiçăo de outro, subalterno, inferior, primitivo, bestializado, por meio da criaçấo de estereótipos que sâo perpetuados pelas ideologias dominantes, permitindo assim, como assinala Bonnici (2003), a demarcaçâo de uma falsa superioridade europeia:

[...] geraçóes de europeus se convenciam de sua superioridade cultural e intelectual diante da "nudez" dos ameríndios; geraçóes de homens, praticamente de qualquer origem, tomavam como fato indiscutível a inferioridade das mulheres. Nesses casos, estabeleceu-se uma relaçăo de poder entre o "sujeito" e o "objeto", a qual năo reflete a verdade (BONNICI, 2003, p. 205).

Muitos săo os exemplos que podem ilustrar as outremizaçóes do subalterno, conforme expóe Said (1990) ao tratar do modo como os colonizadores concebiam os asiáticos e orientais, estabelecendo estereótipos a partir do poder colonial:

[...] orientais ou árabes sâo simplórios, "desprovidos de energia e de iniciativa" e muito dados a "adulaçôes de mau gasto", intriga, simulaçăo e maus tratos aos animais; os orientais sao incapazes de andar em urna estrada ou calcamento (suas mentes desordenadas năo conseguem entender aquilo que o sagaz europeu apreende imediatamente, que estradas e calcamentos sao feitos para andar); os orientais sao mentirosos inveterados, sao "letárgicos e desconfiados", e em tudo se opóem a clareza, integridade e nobreza da raça anglo-saxónica (SAID, 1990, p. 49).

Esse modo de outremizar o subalterno ocorrerá no Brasil com as mulheres negras, conforme veremos ao analisar algumas músicas que tratam da figura da mulata, o que implica a intersecçâo de classe, gênero e raça. Para propor nossa hipótese, subjaz às noçōes pós-coloniais a base analítica do Materialismo Cultural, conforme sintetizado por Maria Elisa Cevasco (2003, p. 148): "o materialismo cultural náo considera os produtos da cultura 'objetos', e sim práticas sociais: o objetivo da análise materialista é desvendar as condiçôes dessa prática e nâo meramente elucidar os componentes de uma obra". Desse modo, podemos apreender que a carreira artística de Elza Soares está vinculada a um complexo de relaçôes/práticas sociais, sendo que algumas dessas relaçôes/práticas sociais perfeitamente elucidadas pelas reflexóes em torno da outremizaçăo. Consequentemente, apreende-se e elucida-se mecanismos ideológicos de dominaçăo na formaçáo social brasileira a partir do lócus específico de enunciaçáo de um sujeito subalterno, bem como busca agenciamento de autonomia e resistência, dado que, afinal, embora os quatro últimos álbuns de Elza Soares visam ser uma "arte progressista" (DAVIS, 2017), os seus primeiros álbuns săo uma estilizaçăo própria da formaçăo ideológica da classe dominante brasileira.

\section{ELZA SOARES, 70 ANOS DE CARREIRA QUE PERMITEM IDENTIFICAR TRANSFORMAÇÕES HISTÓRICO-CULTURAIS NA SOCIEDADE BRASILEIRA}

O estilo musical do início da carreira de Elza Soares, e constante de seu repertório, foi o samba, recebendo inclusive o diploma de Embaixatriz do Samba, em 1971. 
A morfologia do samba brasileiro é forjada no circuito do Atlântico Negro (GILROY, 2001), da trágica experiência da diáspora africana e do horrendo ambiente da escravidăo. Justamente pelo samba surgir no Brasil como consequência de um desdobramento rítmico e musical forjado no Atlântico Negro, deparamo-nos "com a inevitável fragmentaçăo e diferenciaçăo da questâo negra", o que, por sua vez, "torna insustentável o essencialismo cômodo" (GILROY, 2001, p. 92-93).

Concordamos com Paul Gilroy (2001) que a "música e seus gestos comunicativos năo săo expressivos de uma essência que existe fora" dos processos histórico-culturais (GILROY, 2001, p. 221). Trata-se, assim, da necessidade de "encararmos a subjetividade racializada como produto das práticas sociais" (GILROY, 2001, p. 209), de modo que esse ponto de vista implica que năo é possível conceber o "desenvolvimento musical negro [...] como expressáo de um eu racial essencial, imutável e soberano" (GILROY, 2001, p. 93). Essas práticas sociais que afetam a subjetividade de Elza Soares no início de carreira consiste, por um lado, nas estratégias mercadológicas da recém consolidada indústria cultural brasileira, em que se efetuou, para utilizar a expressáo de Ana Maria Rodrigues (1984), uma "espoliaçăo branca do samba negro".

É no bojo dessa transformaçăo do samba em queridinho do Brasil que surge Elza Soares no cenário musical, cuja inserçăo na mídia acreditamos ter ocorrido a partir do binômio exclusáo-inclusấo. A partir da década de 1930, o projeto político do governo Getúlio Vargas, marcado por nacionalismo autoritário, visa construir a expressăo cultural da brasilidade e, para tanto, o samba é escolhido. Estudiosos sobre o tema apontam que isso gerou diversas implicaçóes, devido a especificidade de origem desse estilo musical, isto é, de ser uma música da cultura negra. Conforme explica Napolitano (2010), isso gerou inúmeros conflitos, tendo em vista que o samba trazia fortes traços da cultura negra, como grupo social em boa parte constituída pela parcela da populaçăo egressa recentemente da escravidăo.

A indústria cultural por meio, inclusive, do apoio de política públicas do governo Vargas foi grande aliado nessa intençăo de "embranquecimento" desse estilo musical de origem negra. Rodrigues (1984), Sodré (1979), Guimarăes (1998) e Napolitano (2010) concordam que houve uma incisiva postura de "embranquecimento" do samba, para torná-lo ícone do "ethos" brasileiro. Em conformidade com Sodré (1979), é possível observar que "a classe média" torna-se "produtora sistemática de sambas e começa a fazer passar, por meio do som e da letra, novas significaçóes culturais", aspecto este que consistia em "um movimento de expropriaçăo paulatina do instrumento expressivo de um segmento populacional (pobre, negro) por outro (médio, branco)" (SODRÉ, 1979, p. 37).

Pode-se compreender esse "movimento de expropriaçăo" como mais uma estratégia da burguesia nacional, herdeira da elite colonial, de impedir que o subalterno tenha seu lugar de fala. Por sua vez, Rodrigues (1984) defende o argumento de que o "branqueamento" e "usurpaçăo" das festividades afro-brasileiras representou uma "estratégia ideológica" de afirmaçăo da "democracia racial".

Concordamos com Hall (2005) que "as culturas nacionais, ao produzir sentidos sobre a naçâo, sentidos com os quais podemos nos identificar, constroem identidades", cujos significados estão incorporados "nas histórias que săo contadas sobre a naçáo, memórias que conectam seu presente com seu passado e imagens que dela săo 
construídas" (HALL, 2005, p. 51). Em vista disso, podemos aquilatar que a construçâo do samba como identidade nacional, por mais que fez a classe média se identificar com esse estilo musical afro-brasileiro, ainda perpetuou o seu passado discriminaçáo racial. Essa "conexăo entre presente com o passado" mencionada pelo autor traz à baila a outremizaçăo da mulher negra na figura da mulata, a qual possui arraigadas noçóes coloniais da identidade feminina "mestiça".

\section{1 "Ai, mulata assanhada / fingindo inocente"}

O título dessa seçâo foi retirado da cançâo "Mulata assanhada", lançada em 1956 por Ataulfo Alves e interpretada por Elza Soares no álbum Se acaso você chegasse (1960). A cançấo é paradigmática da outremizaçáo da identidade da mulher negra presente em cançóes do repertório artístico de Elza Soares, que leva em seu bojo a temática da mestiçagem e da democracia racial. Os álbuns A Bossa Negra (1961) e Sambossa (1963) também possuem cançóes que tratam da figura da mulata, respectivamente "As polegadas da mulata" e "Mulata de verdade".

A figura da mulata (termo cuja origem remonta à mula, animal híbrido) permite compreender a interseccionalidade entre raça e gênero. A título de exemplo, citamos Mariza Corrêa (1996) em cujo estudo demonstra que nos romances enquanto o mulato "carrega o peso da ascensáo social, ou do desafio à ordem social, nas suas costas espadaúdas, com sua cintura fina as mulatas, no máximo, provocam descenso social e, no mínimo, desordem na ordem constituída do cotidiano" (CORRÊA, 1996, p. 40). Ainda em conformidade com a autora, a dominaçâo patriarcal está relacionada com o racismo, de modo que

Acredito que a mulata construída em nosso imaginário social contribui, no âmbito das classificaçôes raciais, para expor a contradiçâo entre a afirmaçăo de nossa democracia racial e a flagrante desigualdade social entre brancos e năo brancos em nosso país: como "mulato" é uma categoria extremamente ambígua e fluída, ao destacar dela a mulata que é a tal, parece resolver-se esta contradiçáo, como se se criasse um terceiro termo entre os termos polares Branco e Negro. Mas, no âmbito das classificaçóes de gênero, ao encarnar de maneira tăo explícita o desejo do Masculino Branco, a mulata também revela a rejeiçăo que essa encarnaçấo esconde: a rejeiçâo à negra preta. (CORRÊA: 1996, 50)

Assim, na representaçăo da mulata é enfatizada a sua sexualidade exótica, o caráter pecaminoso ${ }^{2}$. Esse aspecto da sexualidade exótica, na realidade, já é uma outremizaçâo que ocorre desde o período colonial, se perpetuando como imaginário social até os dias atuais, conforme esclarece Carneiro (2003): “[...] o que poderia ser considerado histórias ou lembranças do período colonial permanecem vivos no imaginário social e adquirem novas roupagens e funçōes em uma ordem social supostamente democrática

2 Um trecho em 0 Guarani, de Alencar, é exemplar de uma representaçâo em que a elevaçấo e espiritualidade é apenas agregado à mulher branca, que sâo os "anjos louros", enquanto a mulher negra possui um encantamento pecaminoso: "Vendo aquela menina loura, tâo graciosa e gentil, o pensamento elevava-se naturalmente ao céu, despia-se do invólucro material e lembrava-se dos anjinhos de Deus. Admirando aquela moça morena, lânguida e voluptuosa, o espírito apegava-se à terra; esquecia o anjo pela mulher; em vez do paraíso, lembrava-se de algum retiro encantador, onde a vida fosse um breve sonho". (ALENCAR, 1979, p. 106, grifos nossos) 
que mantém intactas as relaçóes de gênero, segundo a cor e a raça instituídas no período escravista" (CARNEIRO, 2003, p. 60).

Em busca de desvelar essas "novas roupagens" (CARNEIRO, 2003) do preconceito/ objetificaçáo de gênero, năo podemos obviamente conceber "Mulata assanhada", "As polegadas da mulata" e "Mulata de verdade" apenas como cançôes de temática do amor/ paixăo representada pela figura de uma mulher que os eus-líricos desejam e quererem conquistar.

A formaçăo discursiva de "Mulata assanhada" representa a mulata como uma mulher que "tem feitiço no olhar", enfeitiçando os homens, lhes "tirando o sossego":

Ai, mulata assanhada

Que passa com graça

Fazendo pirraça

Fingindo inocente

Tirando o sossego da gente

Ai, mulata se eu pudesse

E se meu dinheiro desse

Eu te dava sem pensar

Essa terra, este céu, este mar

E ela finge que năo sabe

Que tem feitiço no olhar

Ai, mulata assanhada

Ai, meu Deus, que bom seria

Se voltasse a escravidăo

Eu pegava a escurinha

Prendia no meu coraçâo

E depois a pretoria

É quem resolvia a questăo

Ai, mulata assanhada

(SOARES, 1960)

A mulata "finge ser inocente" (SOARES, 1960) em relaçâo ao seu encantamento sexual, mas na realidade é assanhada. A voz lírica se diz disposto a tudo para conquistar a mulata, conforme a segunda estrofe da cançăo. Vê-se que o dinheiro poderia comprar o amor da mulata, mas como este eu-lírico năo possui o suficiente a mulata "finge que năo sabe" (SOARES, 1960) sobre a paixăo dele por ela. A última estrofe é decisiva, indica que a voz lírica está, de fato, disposto a tudo para obter o prazer sexual, inclusive apelando à força, pela obrigaçáo de corpo/objeto comprado e, por isso, clama a "Deus, que bom seria / Se voltasse a escravidāo" (SOARES, 1960). Deparamo-nos aqui com o desejo de tratar as mulheres negras apenas como uma mercadoria: “Eu pegava a escurinha / prendia no meu coraçâo" (SOARES, 1960). 
Talvez possa haver quem veja nessa composiçăo um recurso irônico, que enfatize a liberdade da mulher negra em face do desejo do homem branco, levando em consideraçăo também o fato de que o compositor, Ataulfo Alves, seja um homem negro. Contudo, à luz das análises do feminismo negro, que propóe um olhar intersecional, acreditamos que os versos carregam sentidos patriarcais. bell hooks (2017) nos ajuda a esclarecer esse aspecto problemático, em que também os homens negros nâo se isentam da lógica patriarcal:

Em todas as instituiçóes os homens negros tinham mais poder e autoridade que as mulheres negras. Foi só quando entrei na faculdade que aprendi que os homens negros teriam sido "castrados", que o principal trauma da escravidáo era o de ter privado os homens negros do direito aos privilégios e poderes masculinos, de têlos impedido de atualizar plenamente a "masculinidade"[...]. No mundo real onde cresci, eu tinha visto homens negros ocupando as posiçóes de autoridade patriarcal, exercendo formas de poder masculino a apoiando o sexismo institucionalizado (hooks, 2017, p. 161-162).

Com isso, parece-nos que Ataulfo Alves com a sua composiçấo busca ocupar uma "posiçấo de autoridade patriarcal" (hooks, 2017) ao fazer a alusâo à escravidâo ao falar da paixăo do eu-lírico, apoiando assim o "sexismo institucionalizado" (hooks, 2017) no imaginário social da figura da mulata. Apreende-se, consequentemente, que a outremizaçâo da figura da "mulata assanhada" implica que "corpo está sempre simultaneamente (mesmo que de modo conflituoso) inscrito tanto na economia do prazer e do desejo como na economia do discurso, da dominaçăo e do poder" (BHABHA, 1998, 107).

Em "As polegadas da mulata" (SOARES, 1961), concebe-se que a "mulata é só quem tem aquela graça natural / de quem nasceu pro rebolado" e, por isso,

Samba sem mulata nâo é samba nâo senhor!

É samba triste

Samba só feito pra doutor

Sem a moreneza da mulata rebolando

A gente vai aos poucos

Até desanimando

Mulata é só quem tem aquela graça natural

De quem nasceu pro rebolado

Pois a cor dessa figura quem pintou foi Máe

Natura

Pra deixar o branco todo assanhado

No concurso de beleza

A mulata tá roubada

Porque sempre tá sobrando polegada

(SOARES, 1961) 
Como podemos perceber, a formaçăo discursiva da primeira estrofe indica que o samba e a mulata săo indissociáveis. Essa noçăo de samba, como buscamos esclarecer na seçâo anterior deste artigo, vincula-se ao ideal de identidade nacional. Daí, parecenos lícito concluir que a outremizaçăo/objetificaçăo da mulher negra está fortemente vinculada à noçấo de identidade nacional.

Os versos "Pra deixar o branco todo assanhado / no concurso de beleza" (SOARES, 1961) sâo sintomáticos desse aspecto, pois vinculam-se ao contexto da passagem da mulata para uma categoria ocupacional, que vai ganhar destaque nas casas noturnas, espetáculos, Shows turísticos, concursos de beleza, Globeleza etc. Novamente aparece a imagem de homens enfeitiçados, retirados do sossego (para remeter à composiçáo "Mulata assanhada"), que contribui na representaçăo da mulata sedutora, conduzindo os homens para onde bem ela entender, isto é, escamoteando a lógica patriarcal ao produzir a imagem de que o homem é vítima passiva dos feitiços irresistíveis da mulata. Hooks (1995) contribui nessa questăo, ao esclarecer que

[...] para justificar a exploraçăo masculina branca e o estupro das negras durante a escravidăo, a cultura branca teve de produzir uma iconografia de negras que insistia em representa-lás como altamente dotadas do sexo, a perfeita encarnaçăo de um erotismo primitivo e desenfreado. Essas representaçóes incutiram na consciência de todos a ideia de que as negras eram só corpo, sem mente. A aceitaçăo cultural dessas representaçōes continua a informar a maneira como as negras săo encaradas. Vistas como "símbolos sexuais", os corpos femininos negros săo postos numa categoria, em termos culturais, tida como bastante distante da vida mental" (hooks, 1995, p. 469).

De fato, é possível apreender a omissāo da exploraçăo masculina branca e o estupro das negras nos versos "Pois a cor dessa figura quem pintou foi Măe / Natura" (SOARES, 1961), a violaçấo colonial dos brancos contra mulheres negras e indígenas e a decorrente miscigenaçăo está na origem da construçăo da identidade nacional. Também podemos intuir, em relaçấo à composiçâo "As polegadas da mulata", que "distante da vida mental" (hook, 2017) está "que nasceu pro rebolado" (SOARES, 1961). Vai ao encontro a esses dois significados a composiçấo de Sergio Malta:

Vê se mora no balanço

Desse meu jeitinho manso

Nessa falta, nesse avanço

Que é samba de verdade pra se ver

Vê se mora no desenho

Dessas curvas que eu tenho

Nesse fogo que eu retenho

Pois se pega, faz elouquecer

E é por isso que a mulata de verdade

É melhor que a liberdade

Pra se ter, pra se usar

$[\ldots]$

(SOARES, 1963) 
Em "Mulata de Verdade" vê-se, assim, descriçóes do corpo e comportamento que promove a sedimentaçăo do estereótipo "de que as negras [sâo] só corpo, sem mente", conforme expressa hooks (1995). Essa outremizaçâo também afetou a própria Elza Soares, conforme depoimentos de músicos, produtores musicais entre outros, contidos na sua biografia, escrita por José Louzeiro: "Passei a gostar muito de Elza e a respeitá-la. Sem sombra de dúvida é a mulher pela qual um homem se apaixona fácil: bonita, gostosa, supertalentosa, interiormente rica. Sua sensualidade deixou muito branco assanhado por aí, inclusive eu. Por Billy Blanco" (LOUZEIRO, 1997, p. 345). Embora os depoimentos comecem por nomear os talentos de Elza Soares, sobressai a figura da mulata, a sensualidade do seu corpo.

A artista Elza Soares, nesse caso uma mulher negra, é objetificada e hipersexualizada em vários depoimentos em sua biografia, inclusive endossados pelo seu biógrafo Louzeiro (1997). Vale dizer, tanto em cançôes quanto na biografia de Elza, nos deparamos com uma posiçâo discursiva masculina sempre voltada para a sexualidade da mulher negra, descaracterizando-a como sujeito ("só corpo, sem mente").

\section{2 "Eu náo vou sucumbir" / "Me deixem cantar até o fim"}

Elza Soares obteve certo sucesso no mercado fonográfico em um período em que as(os) negras(os) eram ainda mais silenciados do que contemporaneamente. Sendo uma mulher negra, favelada e fraturada pela fome e pela miséria, ao tornar-se cantora, nâo foi exatamente este o local de enunciaçâo das cançôes de seus primeiros álbuns, o que permite inicialmente atestar o argumento de Spivak (2010), de que "o subalterno, neste caso em especial, a mulher como subalterna, năo pode falar e quando tenta fazê-lo năo encontra os meios para se fazer ouvir" (SPIVAK, 2010, p. 15).

Os seus três primeiros álbuns săo uma estilizaçăo própria da formaçăo ideológica da classe dominante brasileira. Afinal, como esclarece Bonnici (2012) o sujeito é produzido na linguagem e submetido às leis preexistentes do simbólico. Levar em consideraçấo a condiçăo subalterna de Elza permite abrir um novo modo de compreensấo, reconhecendo as marcas de tensâo entre o "fim da colonizaçấo oficial" e sua presença reiterada (em "novas roupagens" conforme a expressâo de Carneiro [2003]), por meio de formaçóes discursivas/ideológicas. O subalterno, cujo termo é criado por Gramsci (1981-1937), indica o "sujeito inferior", referindo-se à pessoa na sociedade que é objeto da hegemonia das classes dominantes (BHABHA, 1998, p. 97; 103).

Situada nesse contexto, Elza, enquanto mulher duplamente subalterna, náo adquire de imediato a liberdade de expressâo e a voz. Ao longo de sua carreira, é possível observar a identificaçâo étnico-racial da cantora em títulos de álbuns, como A Bossa Negra (1960), Sangue, suor e raça (1972), Pilâo + Raça = Elza (1977), Elza negra, negra Elza (1980), Somos todos iguais (1985) e a coletânea Deixa a nega gingar - 50 anos de carreira (2009). Compreendemos que apesar desses títulos de álbuns manifestarem um desejo de autoafirmaçăo, somente a partir dos anos 2000 é que suas cançôes rompem a silenciosa posiçăo de objeto, para construir um discurso politicamente engajado.

O álbum Do cóccix ao pescoço, lançado em 2002, foi produzido por José Wisnik e o título é uma alusâo às lesóes sofridas por Elza em 1999, quando caiu do palco de uma altura de 2 metros. No conjunto, o álbum aponta um distanciamento do samba (aprofundado nos últimos álbuns), pela diversidade de sonoridades a partir de arranjos de naipes 
funk de metais, timbaus baianos, scratches de rap e samples, mas o grande destaque é a composiçăo "A Carne" (composiçăo de Seu Jorge, Marcelo Yuca, Wilson Capellette):

A carne mais barata do mercado é a carne negra ( $4 \mathrm{x})$

Que vai de graça pro presídio

E para debaixo do plástico

Que vai de graça pro subemprego

E pros hospitais psiquiátricos

A carne mais barata do mercado é a carne negra ( $4 \mathrm{x})$

Que fez e faz história

Segurando esse país no braço

O cabra aqui năo se sente revoltado

Porque o revólver já está engatilhado

E o vingador é lento

Mas muito bem intencionado

E esse país

Vai deixando todo mundo preto

E o cabelo esticado

Mas mesmo assim

Ainda guardo o direito

De algum antepassado da cor

Brigar sutilmente por respeito

Brigar bravamente por respeito

Brigar por justiça e por respeito

De algum antepassado da cor

Brigar, brigar, brigar

A carne mais barata do mercado é a carne negra (4x)

(SOARES, 2002)

A formaçăo discursiva da cançăo é o combate ao racismo e às desigualdades brasileiras, visando resgatar a cidadania negada aos afro-brasileiros pela burguesia nacional. Os versos "Que vai de graça pro presídio / E para debaixo do plástico / Que vai de graça pro subemprego" (SOARES, 2002) denunciam a violência policial, a negligência das políticas públicas que năo oferecerem melhores oportunidades de empregos e educaçăo para a populaçấo negra. Ao defender a necessidade de "brigar bravamente por respeito / brigar por justiça" (SOARES, 2002), podemos depreender também uma crítica ao mito da democracia racial, o qual, segundo Abdias do Nascimento (2016), buscou consolidar no imaginário social brasileiro que "que pretos e brancos convivem harmoniosamente, desfrutando iguais oportunidades de existência sem nenhuma interferência, nesse jogo de paridade social, das perspectivas origens raciais ou étnicas" (NASCIMENTO, 2016, p. 36). 
A partir da interpretaçăo dessa composiçấo, acreditamos ter havido na carreira de Elza Soares uma guinada estético-discursiva, que culmina em "Negâo Negra", sua mais recente música, lançada em 24 de julho de 2020, em parceria com o rapper Flávio Renegado, permitindo conquistar seu locus autônomo de enunciaçăo, enquanto mulher negra e subalterna, após 42 anos de trajetória artística, - conquista de voz porque "se transformou num ser politicamente consciente que enfrenta o opressor com antagonismo sem cessar" (BONNICI, 2012, p. 26).

As interaçôes líricas e discursivas que sustentam a composiçâo de "Negâo Negra" apontam, assim como os versos finais de "A Carne", na importância de resistência de negras e negros para superar a sistemática discriminaçăo de uma sociedade estruturalmente racista. As duas primeiras estrofes demarcam a difícil sobrevivência em uma dinâmica de desigualdade estruturalmente erigida para subalternizar a populaçấo negra:

Nunca foi fácil e nunca será

Para o povo preto do preconceito se libertar

Sempre foi luta, sempre foi porrada

Contra o racismo estrutural, barra pesada

Negăo, negăo, negăo, negăo

Negăo, negăo, negăo, negăo

Negra, negra, negra, negra, negra

Negăo, negăo, negăo, negăo

Negăo, negăo, negăo, negăo

Negra, negra, negra, negra, negra

Fala pro homem cordial e a sua falha engrenagem

Meu corpo é livre, com amor, cor e coragem

Pra cada um que cai, choramos rios e mares

Mas nunca calaráo as nossas vozes milenares

Sem gênero ou preceito, humanos em nova fase

Wakanda é o meu mundo, Palmares setor a base

Quem topa esse rolê dá asas à liberdade

No feat filho do rei e a deusa Elza Soares

Todos os dias me levanto

Olho no espelho, sempre me encanto

Com o meu cabelo e a cor da pele dos meu ancestrais

Todas as noites no quarto escuro

Peço a Deus e aos orixás

Que a escravidăo năo volte nunca, nunca, nunca mais

(SOARES/RENEGADO, 2020) 
O preconceito do racismo estrutural, que fornece a reproduçăo da desigualdade e violência, é "barra pesada", porque já é algo normalizado nas formas institucional e cultural. É nesse sentido que Silvio Almeida (2018) caracteriza o racismo estrutural, um processo histórico, político, jurídico e econômico que "cria as condiçôes sociais para que, direta ou indiretamente, grupos racialmente identificados sejam discriminados de forma sistêmica" (ALMEIDA, 2018, p. 38).

Embora nossa análise das composiçôes de "A Carne" e "Negâo Negra" năo seja exaustiva, já conseguimos depreender que elas buscam "empoderar homens e mulheres com as armas educacionais e econômicas que lhe permitiram se tornarem sujeitos de sua própria história e construir seu futuro de tal forma que reflita suas necessidades coletivas como naçăo" (DAVIS, 2017, p. 126). Nesse sentido, ao cantar que mesmo sendo "barra pesada" (SOARES/RENEGADO, 2020) a sistêmica discriminaçấo, Elza canta nas próximas estrofes que esse racismo estrutural "nunca calarâo as nossas vozes milenares" (SOARES/RENEGADO, 2020). Ao contrário do enunciado de "Mulata assanhada", em que a voz lírica clama a "Deus, que bom seria / Se voltasse a escravidáo" (SOARES, 1960) para comprar como uma mercadoria o corpo da mulata, Elza canta em "Negâo Negra" que "todas as noites no quarto escuro / peço a Deus e aos orixás / que a escravidăo nâo volte nunca, nunca, nunca mais" (SOARES/ RENEGADO, 2020).

Como explicar essa transformaçăo discursiva? Uma transformaçăo discursiva que permite Elza Soares se tornar uma figura de resistência, que é ao mesmo tempo uma transformaçăo de identidade e um empoderamento como mulher negra. Como, afinal, surge esse engajamento com uma "arte progressista" de uma cantora que reproduzia padrōes e se limitava a interpretar grandes sucessos já consagrados do samba?

\section{UMA POSSÍVEL CONCLUSÃO, E OS PRÓXIMOS PASSOS DA PESQUISA}

O fato de a carreira artística de Elza Sores iniciar praticamente um século e meio após o processo da independência do Brasil da colonizaçâo de Portugal, nâo tornaria a teoria pós-colonial dispensável? Em nossa pesquisa consideramos de alta relevância náo a dispensar, pois parte de pressupostos teóricos de que a colonizaçáo pode ser concebida além do que um domínio político direto em países, dado que após o contato com a colonizaçấo a cultura segue impregnada das representaçóes de discursos do poder colonial (HALL, 2005; BHABHA, 1998; ASCHCROFT, 1998; 2001; SAID, 1990; SANTOS, 2004; BONNICI, 2012). Evidenciar isso a partir das cançôes de Elza Soares é o objetivo e os próximos passos que queremos trilhar com esta pesquisa, reconhecendo que "Postcolonial popular music studies seeks to examine all uses of popular music for an understanding of the historical and ongoing process of decolonization, recognizing that flag raising in the postcolony alone does not consign the colonial legacy to the past" (LOVESEY, 2017, p. 1)3).

3 Em traduçăo livre: "Os estudos pós-coloniais de música popular pós-colonial buscam examinar todos os usos da música popular para uma compreensấo do processo histórico e contínuo de descolonizaçāo, reconhecendo que apenas o hasteamento da bandeira na pós-colônia nâo remete o legado colonial ao passado". 
A partir de estratégias críticas do pós-colonialismo, esforçamo-nos em demonstrar, à luz das cançôes apresentadas e analisadas até aqui, que a carreira artística de Elza Soares está vinculada a um complexo de relaçôes/práticas sociais. Os três primeiros álbuns de Elza Soares nos fizeram depreender a experiência incompleta da descolonizaçăo, no que se refere à perpetuaçâo da outremizaçăo da mulher negra, da discriminaçấo racial e da lógica patriarcal, e tudo isto, por sua vez, está vinculado a práticas sociais que visam tornar o samba o símbolo da identidade nacional, o que de fato aconteceu por meio de uma incisiva postura de embranquecimento desse estilo musical forjado no Atlântico Negro.

Parece-nos, desse modo, a realizaçăo do contraste dos discursos das cançôes dos primeiros álbuns com os últimos. 0 ano de 2015 é decisivo: é lançado o álbum $A$ mulher do fim do mundo, quebrando um hiato de treze anos sem lançamentos. Em um prazo curto de tempo, Elza Soares lança mais dois álbuns importantes: Deus é mulher, em maio de 2018, e Planeta fome, em setembro de 2019. Nesses três álbuns, a nosso ver, consolida a intençâo de Elsa Soares elaborar, conforme denominou Angela Davis (2017), uma "arte progressista", a partir da qual busca lutar pela "emancipaçăo social, [...] pela libertaçăo negra, despertando a consciência social da comunidade" (DAVIS, 2017, p. 141).

Por exemplo, em Deus é mulher, há a composiçăo "Exu nas escolas" cuja formaçăo discursiva problematizam diversas dinâmicas colonialistas que promoveram a condiçấo de subalternizaçăo. O próprio título do álbum e a música a ele vinculada, "Deus há de ser", se opóe ao tradicional conceito de um "Deus" masculino: "Deus é mâe / e todas as ciências femininas" (SOARES, 2018). Importante lembrar que o cristianismo está intimamente ligado à expansâo ultramarina e à colonizaçăo da América, bem como a lógica patriarcal esteve estreitamente vinculada ao cristianismo, buscando reduzir as mulheres à especificidade de sua condiçăo biológica, em que a maternidade, por exemplo, torna-se um destino obrigatório. Por sua vez, o álbum Planeta fome possui uma formaçâo discursiva vinculada ao recrudescimento político ocorrido particularmente a partir da eleiçâo presidencial de 2018, tendo uma composiçấo exclusiva para esse contexto histórico, que é a cançăo "Blá Blá Blá". Neste álbum, houve a regravaçăo de duas cançôes de Gonzaguinha, "Comportamento Geral" e "Pequena memória para um tempo sem memória"4, compostas por ele como forma de protesto à Ditadura Civil-Militar (1964-1985). Essas regravaçóes nos remetem à perspectiva de Frantz Fanon, segundo a qual o artista ou intelectual deve se preocupar com o passado, a fim de que "se abra o futuro, que é um convite à açăo e base para esperança" (FANON, 1990 apud BONNICI, 2012, p. 37).

Sendo assim, o próximo passo da nossa pesquisa consiste em analisar os quatro últimos álbuns de Elza Soares, observando paralelamente o amplo conjunto de mudanças no panorama das relaçóes raciais brasileiras que ocorreram a partir de 2003, devido

4 Destacamos alguns versos de "Pequena memória para um tempo sem memória": "Memória de um tempo / Onde lutar por seu direito / É um defeito que mata / Sáo tantas lutas inglórias / Sáo histórias que a História / Qualquer dia contará / De obscuros personagens / As passagens, as coragens / Sâo sementes espalhadas nesse chăo / De Juvenais e de Raimundos / Tantos Júlios de Santana / Nessa crença, num enorme coraçáo / Dos humilhados e ofendidos / Explorados e oprimidos / Que tentaram encontrar a soluçâo /, Sáo cruzes sem nomes, sem corpos, sem datas / Memória de um tempo / Onde lutar por seu direito / É um defeito que mata" (SOARES, 2019). 
à ascensăo do Partido dos Trabalhadores ao poder presidencial, que promoveu, por exemplo, a expansâo das políticas de açăo afirmativa para acesso ao ensino superior público de negras(os) . $^{5}$.

O conjunto de mudanças realizadas fez com que esse período se constituísse de esperança e, por sua vez, năo estaria estreitamente vinculado a esse processo histórico-social a guinada estético-discursiva na carreira de Elza Soares? Essa pergunta é importante para o desenvolvimento ulterior da presente pesquisa, particularmente porque o período de 2003-2010 é identificado por Ruy Braga (2012) como “hegemonia lulista", o qual (apesar de suas diversas contradiçōes) permitiu a "autoatividade dos subalternos", isto é, um aumento de mobilizaçăo das "classes subalternas" e dos "movimentos sociais" (BRAGA, 2012, p. 27).

5 Em conformidade com Baptista Silva e Rosemberg (2012, p. 79), "foi em 1995 que o governo brasileiro reconheceu, pela primeira vez, que o país é estruturalmente racista, tendo assumido sua dívida histórica para com os negros. A partir dos anos 1990, articulou-se um forte movimento de reivindicaçăo por políticas de açấo afirmativa para negros (e indígenas). [...] Em outras palavras, novos temas e novas imagens estáo circulando no imaginário brasileiro nesses últimos dez anos". 


\section{REFERÊNCIAS}

ALENCAR, J. 0 guarani. Săo Paulo: Ática, 1979.

ASCROFT, B. et al. Key concepts in post-colonial studies. London: Routledge, 1998.

. Postcolonial transformation. London: Routledge, 2001.

BONNICI, T. O pós-colonialismo e a literatura: estratégias de leitura. Maringá: Eduem, 2012.

BONNICI, Thomas. Teoria e crítica pós-colonialista. In: BONNICI, T. ZOLIN, L. O. (Org.). Teoria literária: abordagens históricas e tendências contemporâneas. Maringá: Eduem, 2003. p. 223-229.

BAPTISTA DA SILVA, Paulo; ROSEMBERG, Fúlvia. Brasil: lugares de negros e brancos na mídia. In: DIJK, Teun A. van (Org.). Racismo e discurso na América. Săo Paulo: Contexto, 2012, p. 73-117.

BHABHA, Homi. O Local da Cultural. Belo Horizonte: EdUFMG, 1998.

. A questâo do "outro": diferença, discriminaçăo e o discurso do colonialismo. In: HOLLANDA, Heloisa Buarque. de (org.). Pós-modernismo e política. Rio de Janeiro: Rocco, 1991, p. 177-203.

BRAGA, Ruy. A transformaçăo do avesso. In: A política do precariado: do populismo à hegemonia lulista. Săo Paulo: Boitempo, 2015, p. 103-162.

CARNEIRO, Sueli. Enegrecer o feminismo: a situaçăo da mulher negra na América Latina a partir de uma perspectiva de gênero. In: ASHOKA (Org.). Racismos contemporâneos. Rio de Janeiro: Takano, 2003, pp. 59-68.

CEVASCO, Maria Elisa. Estudos literários x estudos culturais. In: Dez liçôes sobre estudos culturais. Săo Paulo: Boitempo, 2003, p. 138-154.

CORREAA, Mariza. Sobre a invençâo da mulata. Cadernos Pagu, n 6-7, p. 35-50, 1996.

DAVIS, Angela. Mulheres, cultura e política. Săo Paulo: Boitempo, 2017.

GILROY, Paul. “Joias trazidas da servidāo”: música negra e a política da autenticidade. In: O Atlântico negro: modernidade e dupla consciência. Săo Paulo: Ed. 34; Rio de Janeiro: UCM, CEAA, 2001, p. 157-222.

GUIMARÂES, Maria Eduarda Araujo. Do Samba ao Rap: a música negra no Brasil. 227 f. Tese (Doutorado em Sociologia) - UNICAMP, Campinas, 1998.

HALL. Stuart. A Identidade Cultural na Pós-modernidade. Rio de Janeiro: DP\&A, 2005.

HOOKS, BELL. Ensinando a transgredir: a educaçăo como prática de liberdade. Sâo Paulo: Martins Fontes, 2017.

HOOKS, BELL. Intelectuais negras. Revista Estudos Feministas, v. 3, n. 2, p. 454-478, 1995.

LOUZEIRO, José. Elza Soares: cantando para nâo enlouquecer. Săo Paulo: Editora Globo, 1997.

LOVESEY, Oliver. Decolonizing the Ear: Introduction to "Popular Music and the Postcolonial". Revista Popular Music and Society, v. 40, n 1, p. 1-4, 2017. 
NASCIMENTO, Abdias. O Genocídio do Negro Brasileiro: Processo de um Racismo Mascarado. Săo Paulo: Perspectivas, 2016.

NAPOLITANO, Marcos. Sambistas ou arianos? A crítica racista e a higienizaçăo poética do samba nos anos 1930 e 1940. In: CARNEIRO, Maria Luiza Tucci; CROCI, Frederico. Tempos de fascismos: Ideologia - Intolerância - Imaginário. Săo Paulo: EdUSP, 2010, p.421-432.

RODRIGUES, Ana Maria. Samba Negro, Espoliaçăo Branca. Săo Paulo: Hucitec, 1984.

SAID, Edward. O âmbito do orientarismo. In: Orientalismo: o Oriente como invençâo do Ocidente. Săo Paulo: Companhia das Letras, 1990, p. 41-119.

SANTOS, Boaventura de Sousa. Do Pós-moderno ao Pós-colonial. E para além de um e de outro. Centro de Estudos Sociais, Universidade do Minho, 2004.

SODRÉ, Muniz. Samba, o dono do corpo. Rio de Janeiro: Mauad, 1979.

\section{DISCOGRAFIA ELZA SOARES}

SAMBOSSA. Rio de Janeiro: Gravadora Odeon, 1963. Disponível em: https://immub.org/ album/sambossa

A BOSSA NEGRA. Rio de Janeiro: Gravadora Odeon, 1961. Disponível em: https://immub. org/album/a-bossa-negra

SE ACASO VOCÊ CHEGASSE. Rio de Janeiro: Gravadora Odeon, 1960. Disponível em: https://immub.org/album/se-acaso-voce-chegasse

A Carne. In: DO CóCCIX ATÉ O PESCOÇO. Rio de Janeiro: Gravadora Maianga Discos, 2002. Disponível em: https://immub.org/album/do-coccix-ate-o-pescoco

DEUS É MULHER. Rio de Janeiro: Gravadora Deckdisc, 2018. Disponível em: https:// immub.org/album/deus-e-mulher-1

PLANETA FOME. Rio de Janeiro: Gravadora Deckdisc, 2019. Disponível em: https:// immub.org/album/planeta-fome

Negăo Negra. Single. Rio de Janeiro: Estúdio Tambor, 2020. Disponível em: https://www. youtube.com/watch?v=E087HGB7EU8\&ab_channel=ElzaSoares 